\title{
Experimental and Finite Element Analysis of Steel-Concrete Composite Beams
}

\author{
Dr. Suhaib Yahya Kasim Al-Darzi Inas Mahmood A.H.Al-Juboory \\ Civil Engineering Department, College of Engineering, University of Mosul
}

\begin{abstract}
A new type of perfobond shear connector is suggested, and tested through design and construction of six steel-concrete composite beams separated on three groups formed from standard steel section (W4X13), with total length of $1300 \mathrm{~mm}$. The concrete slab connected to steel section by using three types of mechanical shear connectors namely; stud connector and regular circular hole perfobond connectors in addition to newly suggested type of triangular hole perfobond connector. The beams are experimentally tested using two point load beam test to inspect the effects of connector's type on beam behaviour at yielding and ultimate stages in terms of deflection at mid-span and slip at ends of tested beams. A three dimensional nonlinear finite element model is developed using ANSYS software to simulate beam test up to failure. The results show that, composite beams constructed with newly suggested triangular perfobond connectors developed a strength percentage higher than those with stud connectors, and regular circular perfobond connector. The finite element model validated by comparing with experiments, predicting differences in ultimate resistances of $(0.9 \%$ to $5.7 \%)$ for perfobond connectors and (11.9\% to $19.2 \%)$ for stud connectors.
\end{abstract}

Keywords: ANSYS, Connector, Composite, Finite Element, Perfobond, Stud

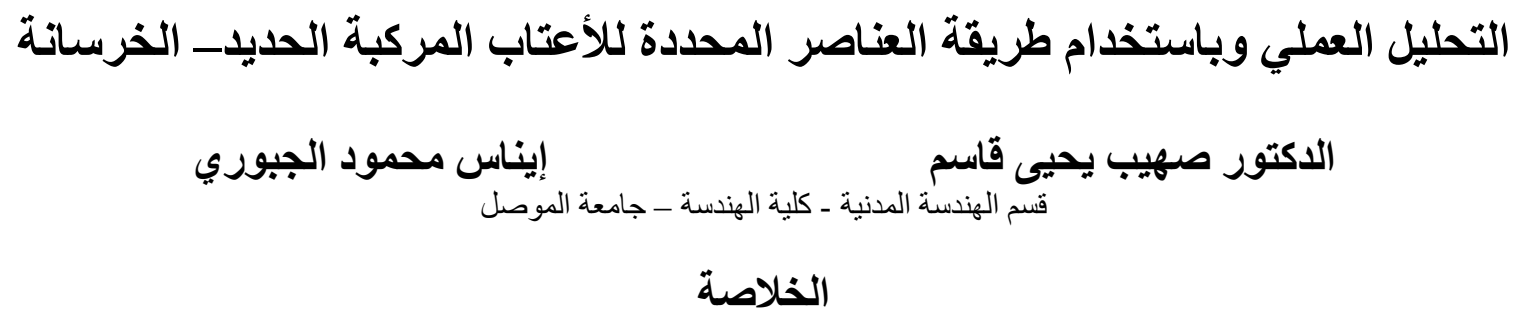

نم تصميم وتنفيذ ستة أعتاب مركبة حديد-خرسانة مقسمة على ثنلاثة مجمو عات باستخدام مقام مقطع حديدي قياسي

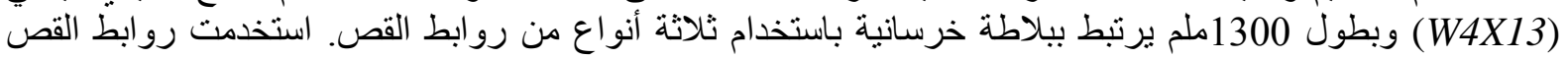

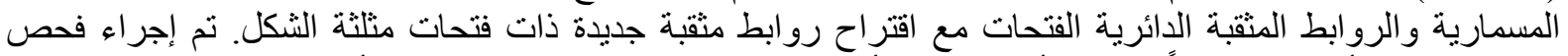

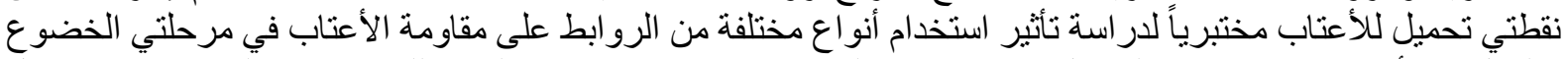

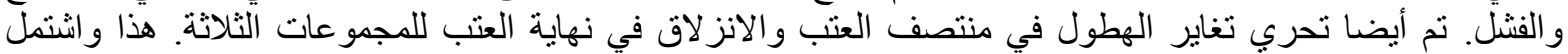

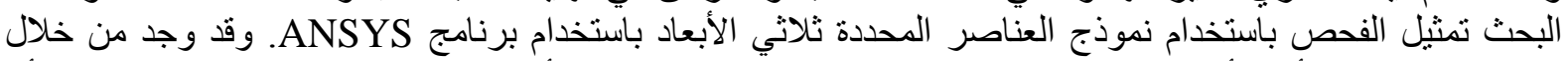

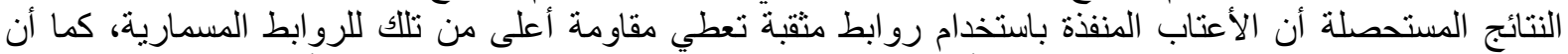

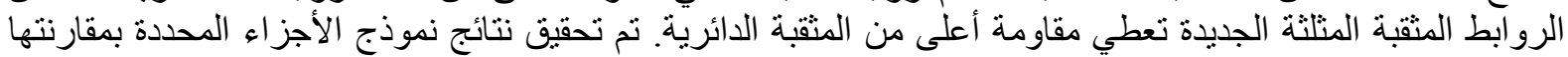

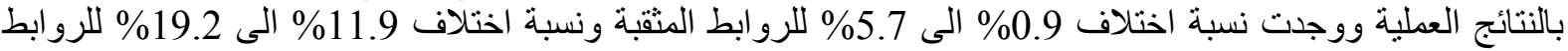
المسمارية.

كلمات مفتاحيه: ANSYS، روابط، مثقبة، مركبة، الأجز اء المحدة، مسمارية

Received: 19 - $10-2011$

Accepted: 5 - 4 - 2012 


\section{Introduction:}

Composite steel-concrete structures are used widely in modern bridge and building construction. A composite member is formed when a steel component, such as an I-section beam, is attached to a concrete component. This type of structure is mainly used due to a reduction in construction depth, savings in steel weight and to rapid construction programs.[1] The real attraction of composite construction is based on having an efficient connection of the steel to the concrete, which allows a transfer of forces and gives the composite members their unique behavior. Therefore, a considerable reference to the behavior of this connection at the interface between the steel and concrete components, will attempt to be demonstrated through investigating the connection between the steel and concrete composite beam. The horizontal shear resistance is one of the most important property affects the behavior of the composite beam, whereas, the resistance depends on several parameters, such as connector's geometrical shapes, no. of connectors, method of connector distribution and dimensions. Since 1922, several researches were conducted to investigate the behavior of shear connector led to suggesting and developing several types of mechanical shear connectors and enhancing those available.[2 \& 3]

In 2003, Nie and Cai investigated the effects of shear slip on the deformation of steelconcrete composite beams by using the equivalent rigidity of composite beams considering three different loading types accounting for slip effects in both fully composite and partially composite beams. The predicted results were compared with experimental results of simply supported and continuous composite beam specimens. It was found that, shear slip in composite beams has a significant contribution to beam deformation. [4]

In 2004, Nie, et.al., conducted a static load tests on 16 steel-concrete composite beams and two steel beams to investigate the shear resisting mechanisms and the strength of composite beams, considering the shear span aspect ratio of the simply supported beams, and the width and thickness of the concrete flanges. The stress in the steel beam was analyzed using theories of elasticity and plasticity based on strain measurements, and the shear resistance of the concrete flange was then obtained by subtracting the steel shear contribution from the total load applied. It was found that the concrete flange could sustain $33 \%$ to $56 \%$ of the total ultimate shear applied to the composite beam specimens, contrary to the typical assumption of neglecting the concrete shear contribution in most design codes and specifications. [5]

In 2005, Liang et.al., investigate the contributions of the concrete slab and composite action to the vertical shear strength of steel-concrete composite beams using three dimensional finite element model to investigate the flexural and shear strengths of simply supported composite beams under combined bending and shear accounting for material and geometrical nonlinear behavior of composite beams. The finite element model's results were verified by comparing with experimental results, then employed to quantify the contributions of the concrete slab and composite action to the moment and shear capacities of composite beams. The researchers also studied the effect of the degree of shear connection on the vertical shear strength of deep composite beams loaded in shear. A design model was proposed as a consistent and economical design procedure for simply supported composite beams.[6]

In 2007, Queiroz et.al., and in 2009, Queiroz et.al., Presented an investigation focused on the evaluation of full and partial shear connection in composite beams using the finite element software ANSYS. It was found that the proposed three-dimensional finite element model is able to simulate the overall flexural behavior of simply supported composite beams, with stud shear connectors, subjected to either concentrated or uniformly distributed loads. 
The load deflection behavior, longitudinal slip at the steel-concrete interface, distribution of stud shear force, and failure modes were investigated. [7 \& 8]

In the present work, the main objective is to conduct a test to investigate the behavior of composite beam with two types of mechanical connectors, namely stud and perfobond shear connector and investigate the applicability of a newly suggested type of perfobond connector. After conducting the test, the composite beam is simulated using three dimensional finite element models considering both geometrical and material nonlinearity to investigate the behavior of the composite beam in more accurate method.

\section{Experimental Program}

Ordinary cement and aggregates with maximum size of $20 \mathrm{~mm}$ are used in concrete. The cement, aggregate and water used in concrete are tested and prepared before construction of composite beam samples. Local cement manufactured in Badosh factory, Mosul is used. A physical and chemical tests are conducted to ensure that the cement are comply with the requirements of Iraqi standards, IQSNo.5,1984.[9] The chemical and physical tests results of cement are shown in Table (1)

Table (1) The chemical and physical tests results of cement

\begin{tabular}{|c|c|c|c|c|c|}
\hline \multicolumn{3}{|c|}{ Chemical test } & \multicolumn{3}{|c|}{ Physical test } \\
\hline Elements & Results \% & IQS:No.5/1984 \% & Properties & results & IQS:No.5/1984 \% \\
\hline $\mathrm{Al}_{2} \mathrm{O}_{3}$ & 5.6 & $3.0-8.0$ & $\begin{array}{c}\text { Fineness remain on } \\
\text { sieve } 170\end{array}$ & $7 \%$ & $\leq 10 \%$ \\
\hline $\mathrm{SiO}_{2}$ & 21.6 & $17.0-25.0$ & Initial Hardening (minute) & 120 & $\geq 45$ minute \\
\hline $\mathrm{Fe}_{2} \mathrm{O}_{3}$ & 2.5 & $0.5-6.0$ & Final Hardening (minute) & 360 & $\geq 600$ minute \\
\hline $\mathrm{CaO}$ & 62.5 & $60.0-67.0$ & $\begin{array}{c}\text { Compressive strength } \\
\text { (MPa) (3 days) }\end{array}$ & 18 & $\geq 16 \mathrm{MPa}$ \\
\hline $\mathrm{SO}_{3}$ & 2.6 & $\leq 2.8 \%$ & $\begin{array}{c}\text { Compressive strength } \\
\text { (MPa) (7 days) }\end{array}$ & 25 & $\geq 24 \mathrm{MPa}$ \\
\hline $\mathrm{MgO}$ & 3.25 & $\leq 5 \%$ & $\begin{array}{l}\text { Tension strength } \\
(\mathrm{MPa}) \text { (3 days) }\end{array}$ & 2.0 & $\geq 1.6 \mathrm{MPa}$ \\
\hline $\mathrm{C}_{3} \mathrm{~S}$ & 36.44 & $31.03-41.05$ & \multirow{4}{*}{$\begin{array}{l}\text { Tension strength } \\
\text { (MPa) (7 days) }\end{array}$} & \multirow[t]{4}{*}{3.5} & \multirow[t]{4}{*}{$\geq 2.4 \mathrm{MPa}$} \\
\hline $\mathrm{C}_{2} \mathrm{~S}$ & 34.20 & $28.61-37.90$ & & & \\
\hline $\mathrm{C}_{3} \mathrm{~A}$ & 12.07 & $11.96-12.30$ & & & \\
\hline $\mathrm{C}_{4} \mathrm{AF}$ & 7.98 & $7.72-8.02$ & & & \\
\hline
\end{tabular}

A local river sand is used as a fine aggregate in concrete admixture, after making a sieve analysis and fined to within the range of medium sand in accordance with (B.S.882:1992) [10], with a fineness modulus of 2.81 and clay percentage $1.4 \%$ as shown in Table (2) and Fig.(1). A local river gravel with maximum aggregate size of $20 \mathrm{~mm}$, according to B.S.882:1992[10], having sieve analysis shown in Table (2a and 2b) and Fig.(1) is used as a coarse aggregate in concrete admixture. Another physical properties of coarse and fine aggregate are shown in Table(3). A normal drinking (tap water) is used for mixing of concrete. 
Table (2a) Physical Properties and Sieve Analyses Results of Sand compared with B.S.882:1992

\begin{tabular}{|c|c|c|c|c|c|}
\hline Sieve size (mm) & Limits \% & \% Passing & $\begin{array}{c}\text { Coarse } \\
\text { limits\% }\end{array}$ & $\begin{array}{c}\text { Medium } \\
\text { limits\% }\end{array}$ & $\begin{array}{c}\text { Fine } \\
\text { limits\% }\end{array}$ \\
\hline 5 mm No.4 & $89-100$ & 100 & - & - & - \\
\hline $2.36 \mathrm{~mm}$ No.8 & $60-100$ & 86 & $60-100$ & $65-100$ & $80-100$ \\
\hline $1.18 \mathrm{~mm}$ No.16 & $30-100$ & 73.5 & $30-90$ & $45-100$ & $70-100$ \\
\hline $600 \mu \mathrm{m}$ No.30 & $15-100$ & 44 & $15-54$ & $25-80$ & $55-100$ \\
\hline $300 \mu \mathrm{m}$ No.50 & $5-70$ & 12 & $5-40$ & $5-48$ & $5-70$ \\
\hline $150 \mu \mathrm{m}$ No.150 & $0-15$ & 3.5 & - & - & - \\
\hline
\end{tabular}

Table (2b) Sieve Analyses Results of Gravel Compared with B.S.882:1992

\begin{tabular}{|c|c|c|}
\hline Sieve size (mm) & \% Passing & General limits of gravel (5-20) mm \% \\
\hline $20 \mathrm{~mm} .3 / 4$ in & 100 & $90-100$ \\
\hline $14 \mathrm{~mm} .5 / 8$ in & 65 & $40-.80$ \\
\hline $10 \mathrm{~mm} .3 / 8$ in & 56 & $30-60$ \\
\hline $5 \mathrm{~mm} .3 / 16$ in & 1 & $0-10$ \\
\hline
\end{tabular}

Table (3) Physical Properties of Sand and Gravel

\begin{tabular}{|c|c|c|c|}
\hline $\begin{array}{c}\text { Type of } \\
\text { aggregate }\end{array}$ & $\begin{array}{c}\text { Density } \\
\left(\mathbf{k g} / \mathbf{m}^{\mathbf{3}}\right)\end{array}$ & $\begin{array}{c}\text { Specific } \\
\text { weight }\end{array}$ & $\begin{array}{c}\text { Absorption } \\
\mathbf{( \% )}\end{array}$ \\
\hline Sand & 1666 & 2.68 & 3.092 \\
\hline Gravel & 1676 & 2.71 & 1.01 \\
\hline
\end{tabular}

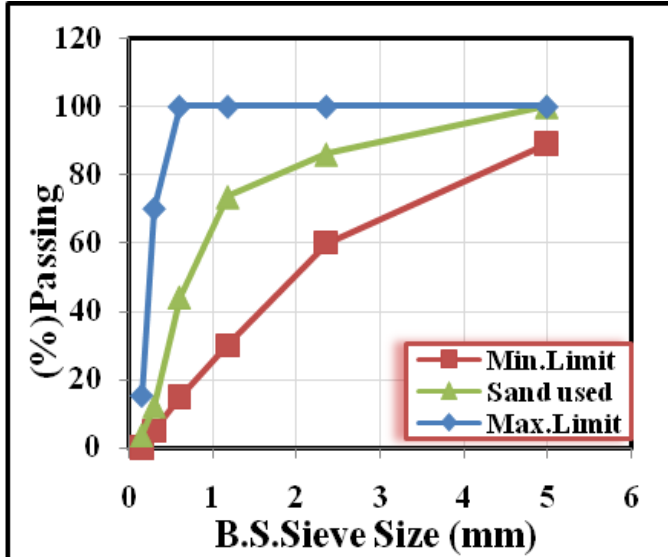

(a) Sand

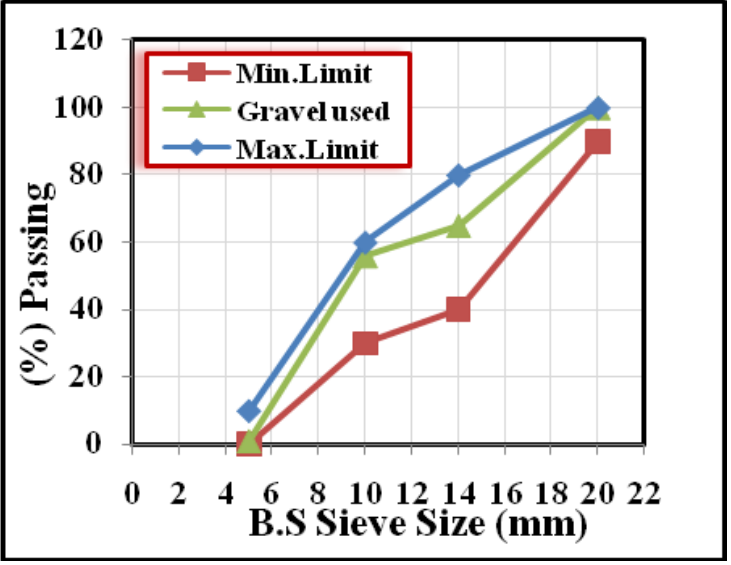

(b) Gravel

Figure (1) Sieve Analysis of Sand and Gravel

Several mixes are prepared to get the required compressive strength of concrete. A mix with percentage (cement: sand: gravel /water) (1:2.46:3.3/0.45) are used with slump of $(90 \mathrm{~mm})$. The average concrete compressive strength of standard cylinder $\left(f c^{\prime}=21 \mathrm{MPa}\right)$ is determined from standard compression tests of six concrete cubes $150 \times 150 \times 150 \mathrm{~mm}$, given as $(f c u=26.167 \mathrm{MPa})$ by assuming that $f c^{\prime}=0.8 f c u$ conducted according to ASTM specification.

Steel beams used in the specimen construction are standard hot-rolled steel shape (W4X13), with total length of $1300 \mathrm{~mm}$ connected to $100 \mathrm{~mm}$ thickness concrete slab with $200 \mathrm{~mm}$ width, as shown in Fig.(2). An average steel yield strength $(f y=331 \mathrm{MPa}$ ) and ultimate strength of (fult. $=465 \mathrm{MPa}$ ) are obtained from uniaxial tensile test of six samples taken from flange and web of steel section. The same test is used for $10 \mathrm{~mm}$ diameter 
reinforcement bars and found that the yield strength $(f y=562 \mathrm{MPa})$ and ultimate strength of $(f u l t .=675 \mathrm{MPa})$. The results of steel section, reinforcement and concrete strength are shown in Table (4).

Table (4) Steel Section and Reinforcement Yield Strength and Concrete Compressive Strength

\begin{tabular}{|c|c|c|c|c|c|}
\hline Steel Sec. & fy $M P a$ & Concrete cube & fcu $M P a$ & Reinf. Bar & fy $M P a$ \\
\hline 1 & 340 & 1 & 28 & 1 & 565 \\
\hline 2 & 325 & 2 & 24 & 2 & 555 \\
\hline 3 & 328 & 3 & 25 & 3 & 569 \\
\hline 4 & 330 & 4 & 26 & 4 & 557 \\
\hline 5 & 338 & 5 & 28 & 5 & 561 \\
\hline 6 & 324 & 6 & 26 & 6 & 563 \\
\hline Average & $\mathbf{3 3 1}$ & Average & $\mathbf{2 6 . 2}$ & Average & $\mathbf{5 6 1 . 2}$ \\
\hline
\end{tabular}

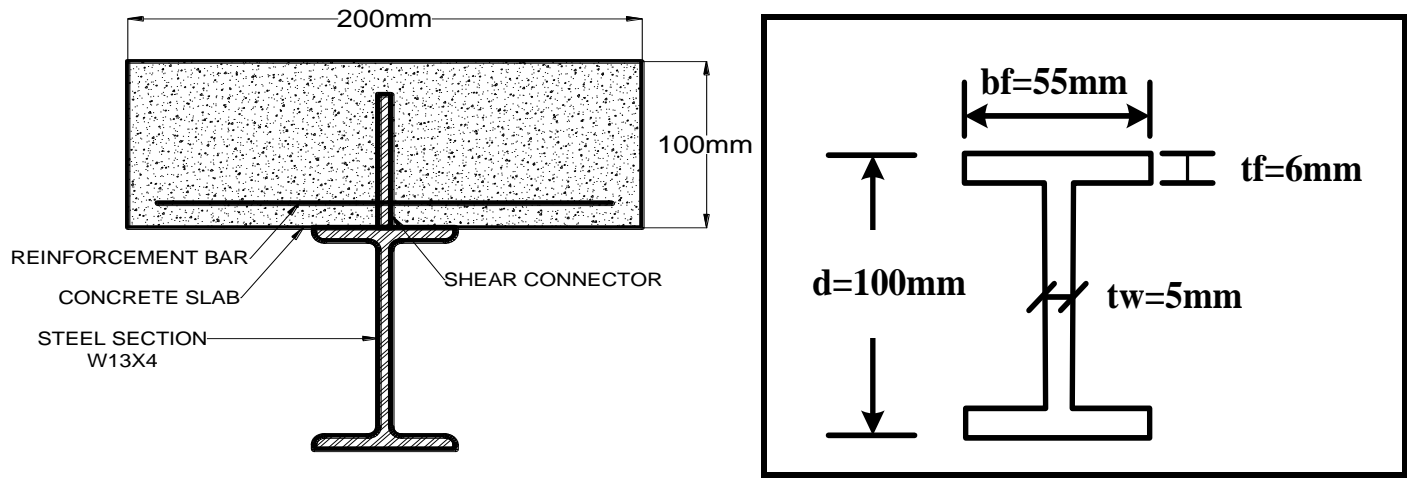

Figure (2) Geometry of steel section and composite beam Sample

The Extensometer is used to measure the displacement during the uniaxial tensile tests of steel sections and from the stress-strain relationships, shown in Fig. (3), the modulus of elasticity are found to be Ess=194350MPa and Esr=187330MPa for steel section and steel reinforcement respectively.

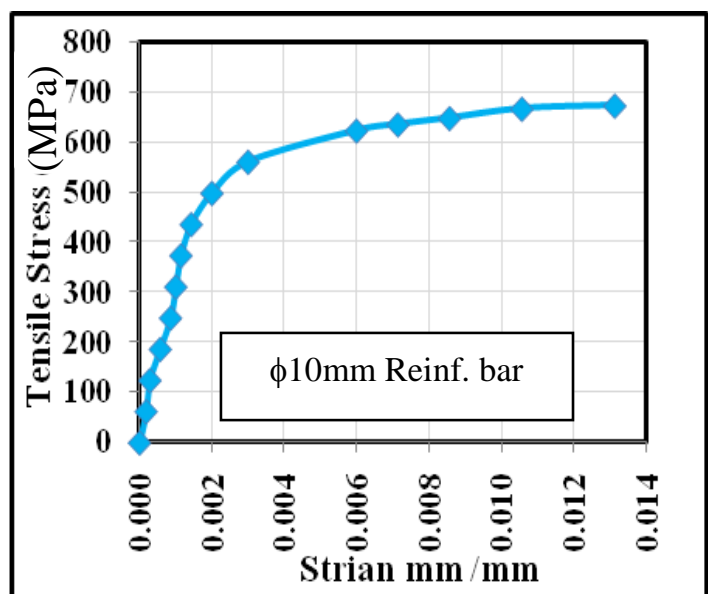

(a) Reinforcement Bar

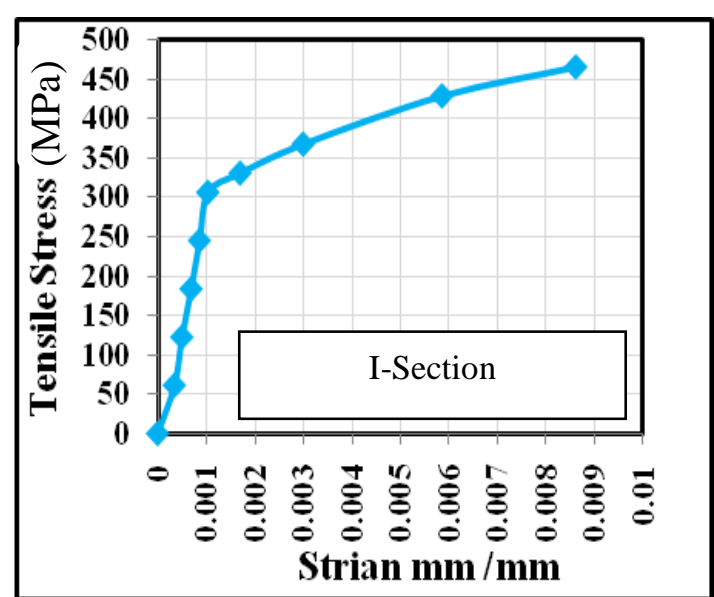

(b) Steel Section

Figure (3). Stress-Strain Relationship of Steel Sections and Reinforcement.

Steel connectors used in the specimen construction are headed stud shear connector (12.5m diameter, and $80 \mathrm{~mm}$ height), perfobond connectors with circular holes, (thickness $=4 \mathrm{~mm}$, height $=80 \mathrm{~mm}$, and hole diameter $=40 \mathrm{~mm}$ ) and perfobond connectors with triangular 
holes, (thickness $=4 \mathrm{~mm}$, height $=80 \mathrm{~mm}$, and hole base $=50 \mathrm{~mm}$, hole height $=50 \mathrm{~mm}$ ), as shown in Fig.(4). An average yield strength and ultimate strength of each type of connectors are obtained from uniaxial tensile test as listed in Table (5).

Table (5) Yield Strength, Ultimate Strength and Modulus of Elasticity of Connectors

\begin{tabular}{|c|c|c|c|}
\hline Type of connector & $\begin{array}{c}\text { Yield Strength } \\
\text { (MPa) }\end{array}$ & $\begin{array}{c}\text { Ultimate } \\
\text { (MPa) Strength }\end{array}$ & $\begin{array}{c}\text { Modulus of Elasticity } \\
\text { (MPa) }\end{array}$ \\
\hline Headed Stud & 582 & 698 & 197500 \\
\hline Perfobond with Circular holes & 562 & 675 & 194350 \\
\hline Perfobond with Triangular holes & 562 & 675 & 194350 \\
\hline
\end{tabular}

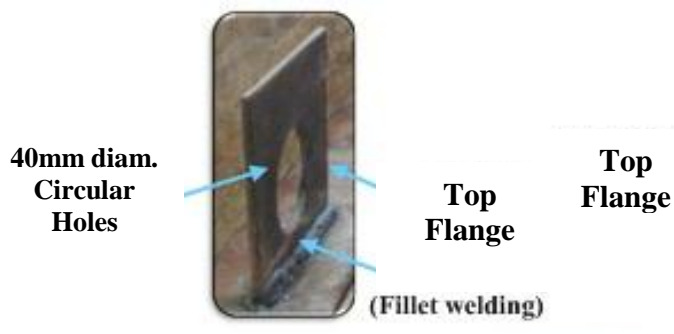

(b) Perfobond Connector with Circular Holes

$h=50 \mathrm{~mm}, \mathrm{~b}=50 \mathrm{~mm}$

(c) Perfobond Connector with Triangular Holes

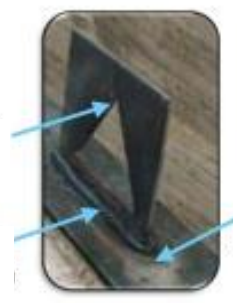

(a) Headed Stud Connector

Flange

Figure (4) Headed stud, Circular and Triangular Connectors.

A total of six composite beams are tested in the civil engineering laboratory, in Mosul University. Two composite steel beams with seven headed stud shear connector are designed and constructed in addition to two beams with circular perfobond connectors. Finally, another two beams with the newly suggested triangular perfobond connectors are constructed. The experimental work considered the effect of using different types of shear connectors on slip and deflection of composite beam. The test groups are summarized in Table (6).

The shear connectors are welded to the steel beam by qualified welders, following a standard procedure. A minimum number of rebars with diameter of $10 \mathrm{~mm}$ are used as a reinforcement in the concrete flange for both longitudinal and transverse directions. The concrete flanges are formed with wood forms, as shown in Fig.(5), and cast at the laboratory. After concrete casting the concrete surfaces of the beams were kept moist with wet burlap for 3 days. The wood forms are then removed and the specimens are cured in air-dry conditions until testing.

Table (6) Testing Matrix and Experimental Results

\begin{tabular}{|c|c|c|c|c|c|}
\hline Specimen & Connector type & $\begin{array}{c}\text { Exp. } \\
\boldsymbol{P}_{\text {yield }}(\boldsymbol{k N})\end{array}$ & $\begin{array}{c}\text { Exp. } \boldsymbol{P}_{\text {ult. }} \\
(\boldsymbol{k N})\end{array}$ & $\begin{array}{c}\text { Exp. } \\
\boldsymbol{\delta}_{\text {ult. }}(\boldsymbol{m m})\end{array}$ & $\begin{array}{c}\text { Exp. Slip } \\
(\boldsymbol{m m})\end{array}$ \\
\hline BHS1 & Headed stud & 138 & 176 & 8.35 & 1.49 \\
\hline BHS2 & Headed stud & 148 & 192 & 10.52 & 1.83 \\
\hline BCPB1 & Circular perfobond & 160 & 214.075 & 10.58 & 1.91 \\
\hline BCPB2 & Circular perfobond & 160 & 206.03 & 11.89 & 1.34 \\
\hline BTPB1 & Triangular perfobond & 170 & 210 & 10.13 & 1.34 \\
\hline BTPB2 & Triangular perfobond & 171 & 215.85 & 9.37 & 1.18 \\
\hline
\end{tabular}




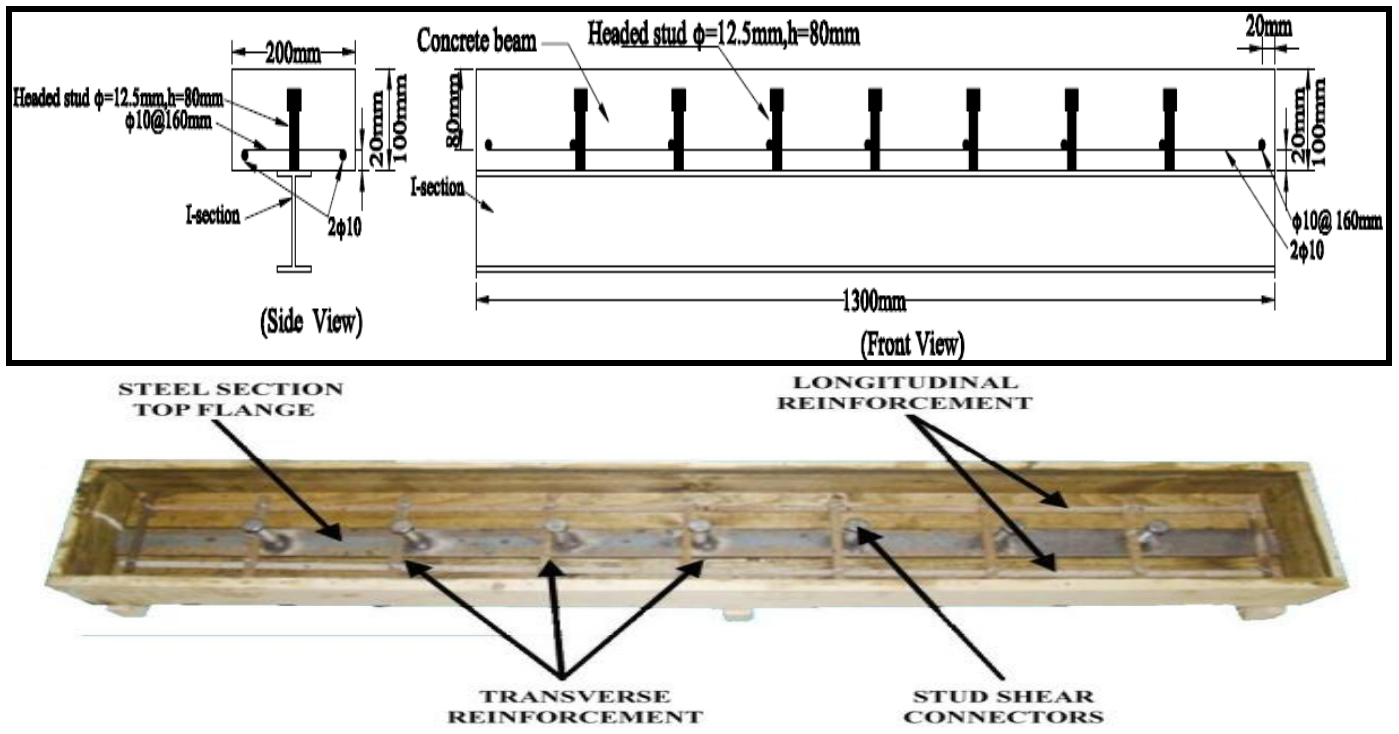

Figure (5-a) Beam with Headed stud connector

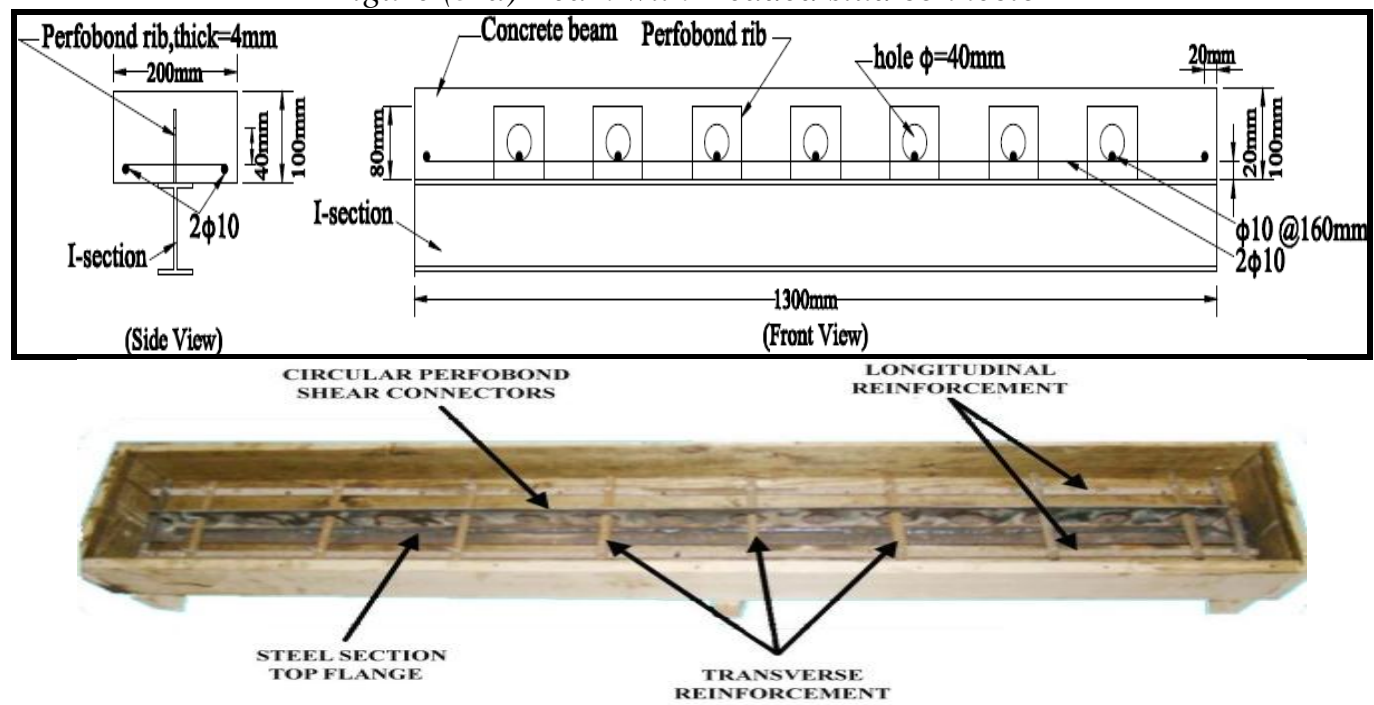

Figure (5-b) Beam with Circular Perfobond connector

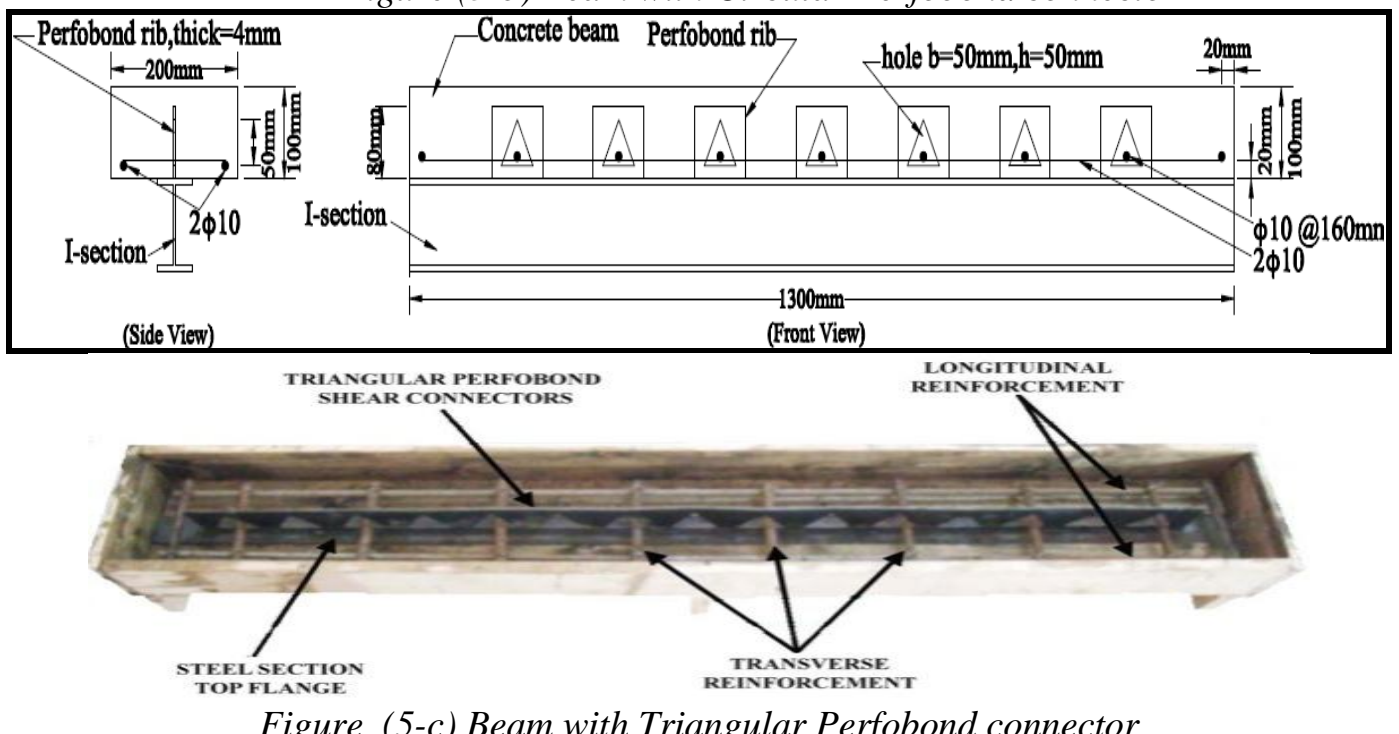

Figure (5-c) Beam with Triangular Perfobond connector

Figure (5) Steel parts, connectors and wood forms of the composite beam 
The composite beam specimens are supported at its ends, with span $1200 \mathrm{~mm}$ between supports. A $500 \mathrm{kN}$ hydraulic jack is used to apply a two points load test with a monotonic load applied at the top of concrete flange through a distribution beam and two cross shafts, generating the loading condition shown in Fig.(6). The test setup generates a two shear spans near the ends and a pure bending span in the middle of the simply supported beam. The load is gradually applied and monitored and recorded using a load cell against the slip at ends and deflections at mid-span, recorded using three transducers with an accuracy of $(0.0001 \mathrm{~mm})$.

During testing of the specimens, a diagonal shear cracks are observed at the bottom of the concrete flange of most specimens, these cracks are initiated at different load stages, then extended further and corresponded to the increasing of the load applied. The small flexural cracks at the middle portion are developed and observed in some specimens. The final failure modes of all specimens are the shear failure in concrete flange after generating major shear cracks, as shown in Fig.(7).

The tested groups and test results listed in Table (6), show that the composite beams with the newly suggested triangular perfobond connector (BTPB-Group) give the highest yield strength and the highest average ultimate strength, while the beams with headed stud shear connectors (BHS-Group) give the lowest yield strength and lowest ultimate strength. As well as, the (BTPB-Group) produced the lowest slip and both the BHS-Group and BCPBGroup produced the highest slip, at ultimate stage. The deflections are varied between the three groups; it's clearly shown that the $B C P B$-Group gives the highest deflection. The tests results of the three groups are plotted in Figs.(8 and 9) in terms of load-slip at end of beam and load-deflection at mid-span of beam respectively.

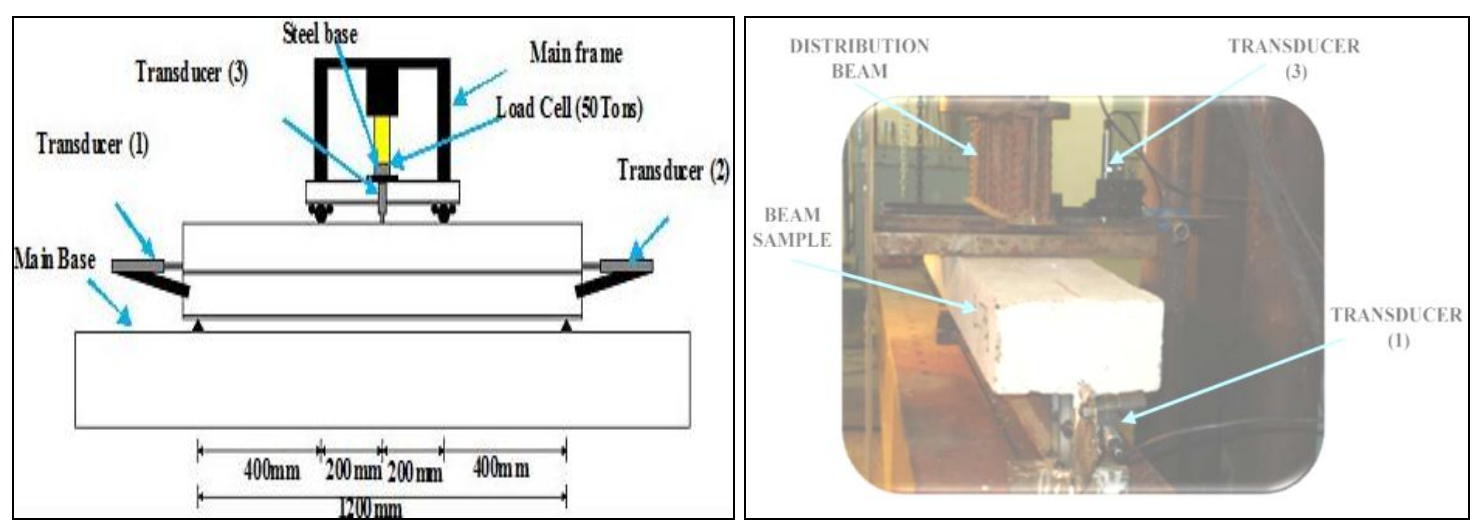

Figure (6) Dimensions and Loading Condition of Beam Specimen

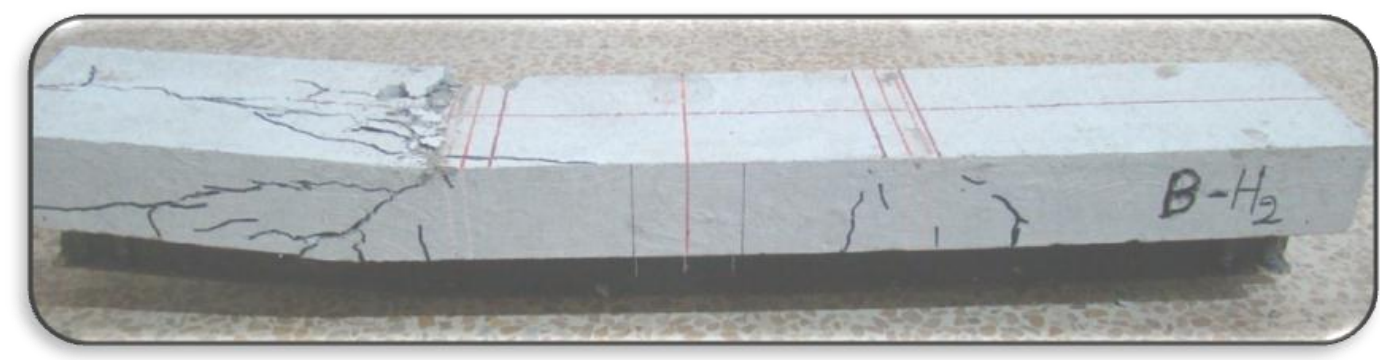

Figure (7) Failure Shape of Tested Beam Sample 


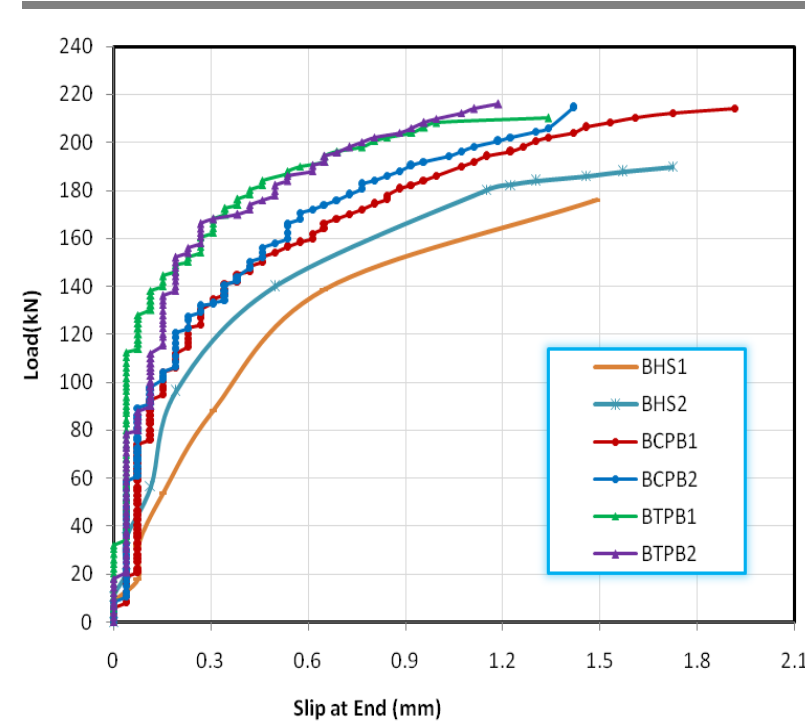

Figure (8) Load-Slip Test Results

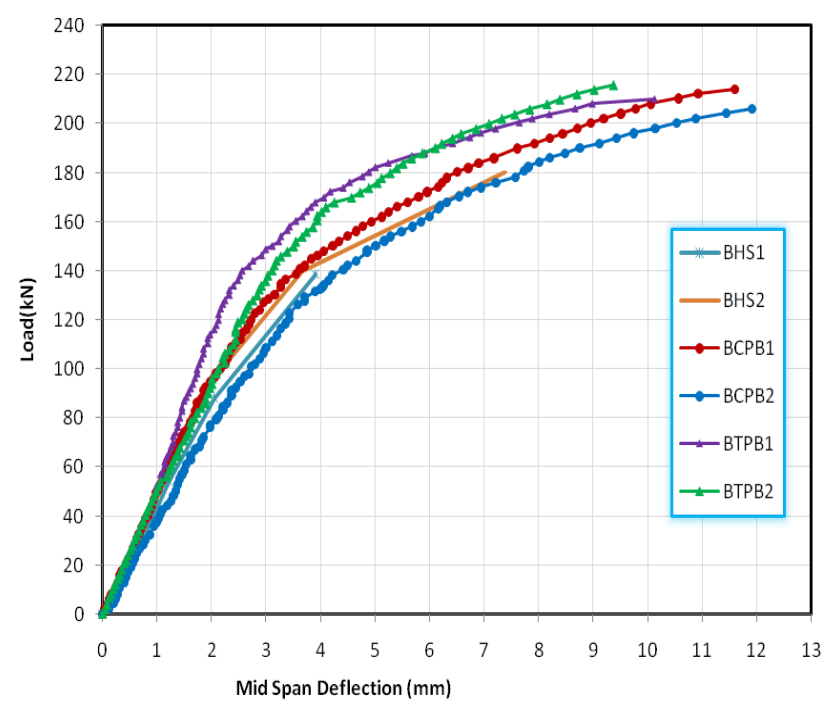

Figure (9) Load-Deflection Test Results

\section{Finite Element Analysis}

The finite element method using general-purpose nonlinear finite element analysis packages ANSYS is adopted to be used for investigating the behavior of the composite beam. The shell (SHELL43) element defined by four nodes having six degrees of freedom at each node, as shown in Fig.(10), is used for the steel section simulation. This element allows for plasticity, creep, stress stiffening, large deflections, and large strain capabilities.[11] The solid (SOLID65) element has eight nodes and three degrees of freedom at each node is used for concrete slab simulation with reinforcing bars (rebars) for both longitudinal and transverse directions smeared throughout the elements, as shown in Fig.(10). This element is capable of cracking (in three orthogonal directions), crushing, plastic deformation, and creep, while the rebars are capable of sustaining tension and compression forces and plastic deformation and creep. [11]

In the present work, making use of symmetry, one-half of the beam is modeled, as shown in Fig.(11). A mesh size of $25 \times 25 \times 50 \mathrm{~mm}$, and mesh size of $25 \times 50 \mathrm{~mm}$ are adopted for SOLID65 elements and SHELL43 elements respectively. The stress-strain relationship of steel section material and reinforcement is linear elastic up to yielding. Von-Mises yield criterion with bilinear isotropic hardening is used to simulate steel section and steel reinforcement behavior at the nonlinear stage. The bilinear stress-strain curve starting at the origin with positive stress and strain values, the initial slope of the curve is taken as the elastic modulus of the steel, at the specified yield stress, the curve continues along the second slope defined by the tangent modulus. [11 \& 12]

The Drucker - Prager yield criterion associated with the flow rule is used to represent the concrete slab behavior.[13] The plasticity and creep formulations used for concrete material are the rate-independent plasticity, using the model of cracking and crushing capabilities, which predicts either elastic behavior, cracking behavior or crushing behavior. If cracking or crushing behavior is predicted, the elastic, stress-strain matrix is adjusted for each failure mode.

This material model predicts elastic behavior, cracking behavior or crushing behavior. If elastic behavior is predicted, the concrete is treated as a linear elastic material. If cracking or crushing behavior is predicted, the elastic, stress-strain matrix is adjusted for each failure mode. The presence of a crack at an integration point is represented through modification of the stress-strain relations by introducing a plane of weakness in a direction normal to the 
crack face. Also, a shear transfer coefficient, is introduced in the program, which represents a shear strength reduction factor for those subsequent loads which induce sliding (shear) across the crack face. The stress-strain relations for a material that has cracked in then justified.

However, Fig. (10c) shows the strength of cracked condition. Whereas, the superscript $(c k)$, which signifies the stress strain relations refer to a coordinate system parallel to principal stress directions with the $\left(x^{c k}\right)$ axis perpendicular to the crack face, and $\left(R^{t}\right)$ which is the slope (secant modulus) works with adaptive descent and diminishes to 0.0 as the solution converges. Where; $(\mathrm{ft})$ is the tensile cracking stress, $(\mathrm{Tc})$ is multiplier for amount of tensile stress relaxation. If the crack closes, then all compressive stresses normal to the crack plane are transmitted across the crack and only a shear transfer coefficient for a closed crack is introduced.[14]

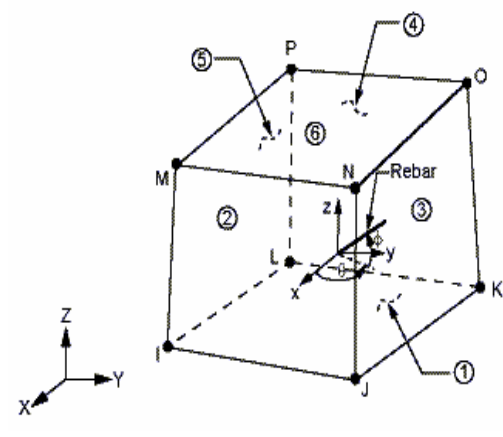

(a) Solid65 brick element

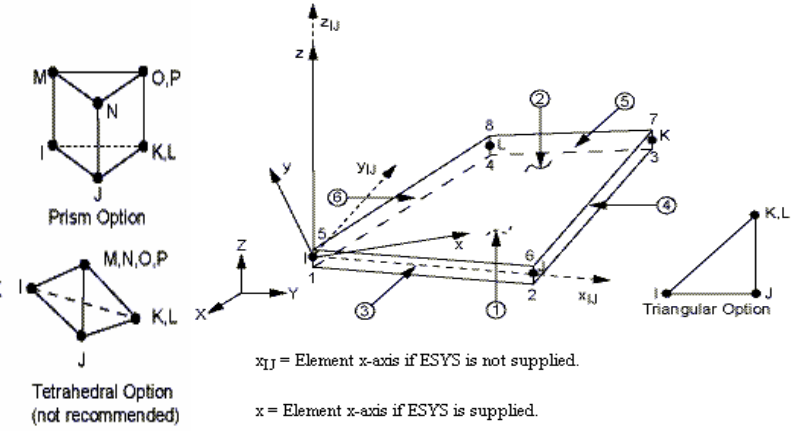

(b) Shell43 element

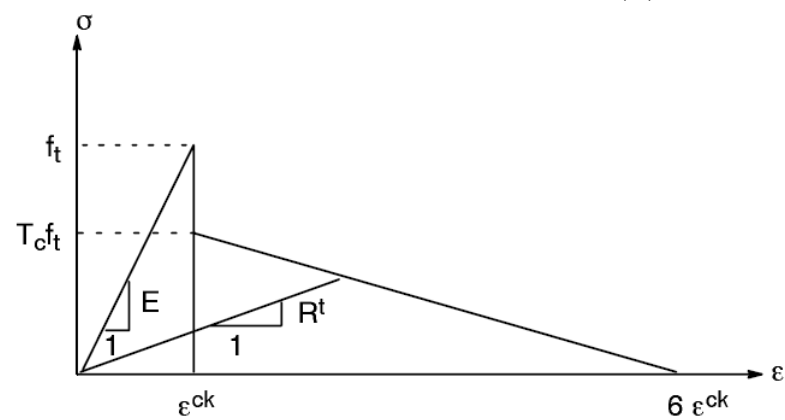

(c) Strength of Cracked Condition

Figure (10) Elements used in finite element analysis and Strength of Cracked Condition

In geometrical nonlinearity, the large strain analyses account for the stiffness changes that result from changes in an element's shape and orientation, the procedure requires that strain increments must be restricted to maintain accuracy, therefore, the total load broken into smaller steps. The out-of-plane stiffness of a structure is significantly affected by the state of in-plane stress in that structure. This coupling between in-plane stress and transverse stiffness, known as stress stiffening, which is obtained using small deflection or linear theory. [14]

The connection between steel section and concrete slab is treated by using coupling of coincident nodes, allowing the nodes to move separately in the x-direction, and moved together in the z-direction and y-direction.

The finite element analyses conducted by applying the loads gradually, start with $10 \mathrm{kN}$ at the first step then automated step are used up to failure. The results of each step are printed before moving to the next step. The program still computing until the failure occurred in either concrete or steel elements, the cracked elements increased till the solution stop converging, at that time the model are failed.

The finite element analysis results are presented in terms of the yield load $\left(P_{\text {yield }}\right)$, from the load slip curve, and ultimate load $\left(P_{u l t .}\right)$ which are listed in Table (7). The deflection 
at mid span of beam at ultimate stage $\left(\delta_{u l t .}\right)$ and slip at end of beam at ultimate stage produced from the finite element analysis are listed in Table (8). In order to investigate the efficiency of the model in simulating the beam test, the results are traced through the loading steps and compared with those obtained experimentally at the same loading level. The variation of finite element to experimental deflection ratio $(\alpha)$ is adopted and plotted along the different load stages up to failure as shown in Fig. (12). The variation of finite element to experimental slip ratio $(\beta)$ with different load stages are also shown Fig. (13). As well as, the finite element and experimental results are plotted in terms of load-deflection curves along the different load stages up to failure as shown in Fig. (14), and plotted in terms of load-slip curves along the different load stages up to failure as shown in Fig.(15).

Table (7) Experimental and Finite Element Yield and Ultimate loads

\begin{tabular}{|c|c|c|c|c|c|c|}
\hline Specimen & $\begin{array}{c}\text { Exp. } \\
\boldsymbol{P}_{\text {vield }}(\boldsymbol{k} \boldsymbol{N})\end{array}$ & $\begin{array}{c}\boldsymbol{F . E .} \\
\boldsymbol{P}_{\text {vield }}(\boldsymbol{k} \boldsymbol{N})\end{array}$ & \% Difference & $\begin{array}{c}\text { Exp. } \boldsymbol{P}_{\text {ult. }} \\
(\boldsymbol{k N})\end{array}$ & $\begin{array}{c}\text { F.E. } \\
\boldsymbol{P}_{\text {ult. }}(\boldsymbol{k} \boldsymbol{N})\end{array}$ & \% Difference \\
\hline BHS1 & 138 & 179.5 & 23.1 & 176 & 217.8 & 19.2 \\
\hline BHS2 & 148 & 179.5 & 17.5 & 192 & 217.8 & 11.9 \\
\hline BCPB1 & 160 & 179.5 & 10.9 & 214.05 & 217.8 & 1.7 \\
\hline BCPB2 & 160 & 179.5 & 10.9 & 206.03 & 217.8 & 5.4 \\
\hline BTPB1 & 170 & 179.5 & 5.3 & 210 & 217.8 & 3.6 \\
\hline BTPB2 & 171 & 179.5 & 4.7 & 215.85 & 217.8 & 0.9 \\
\hline
\end{tabular}

Table (8) Experimental and Finite Element Deflection and Slip at Failure

\begin{tabular}{|c|c|c|c|c|c|c|}
\hline Specimen & $\begin{array}{c}\text { Exp. } \\
\boldsymbol{\delta}_{\text {ult. }}(\mathbf{m m})\end{array}$ & $\begin{array}{c}\text { F.E. } \\
\boldsymbol{\delta}_{\text {ult. }}(\mathbf{m m})\end{array}$ & \% Difference & $\begin{array}{c}\text { Exp. Slip } \\
(\mathbf{m m})\end{array}$ & $\begin{array}{c}\text { F.E. Slip } \\
(\mathbf{m m})\end{array}$ & \% Difference \\
\hline BHS1 & 8.35 & 12.160 & 31.3 & 1.49 & 1.92 & 22.4 \\
\hline BHS2 & 10.52 & 12.160 & 13.5 & 1.83 & 1.92 & 4.7 \\
\hline BCPB1 & 11.58 & 12.160 & 4.8 & 1.91 & 1.92 & 0.5 \\
\hline BCPB2 & 11.89 & 12.160 & 2.2 & 1.34 & 1.92 & 30.2 \\
\hline BTPB1 & 10.13 & 12.160 & 16.7 & 1.34 & 1.92 & 30.2 \\
\hline BTPB2 & 9.37 & 12.160 & 22.9 & 1.18 & 1.92 & 38.5 \\
\hline
\end{tabular}

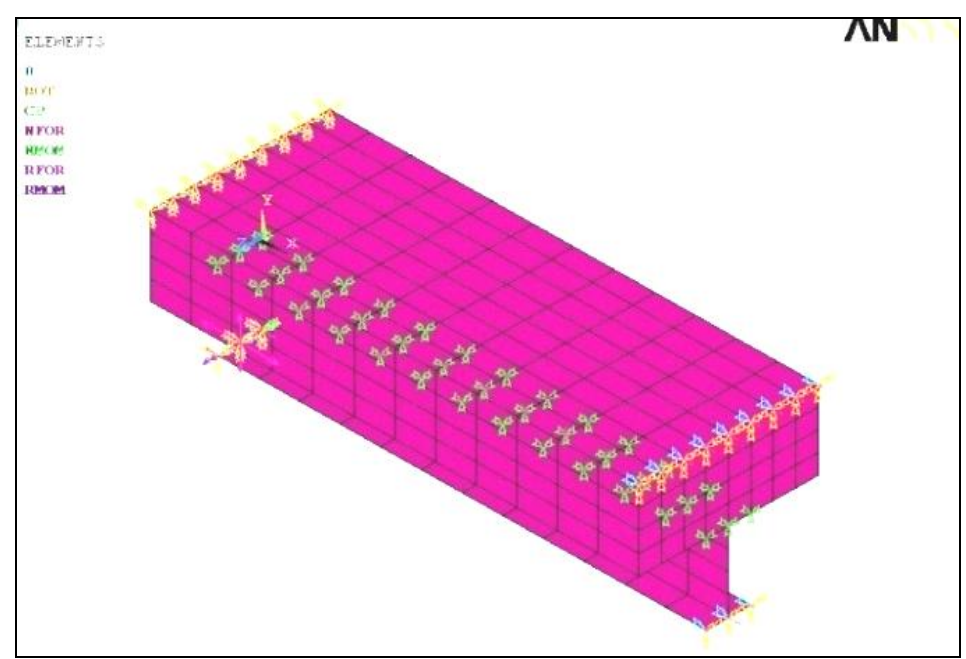

Figure (11) Finite Element Model. 


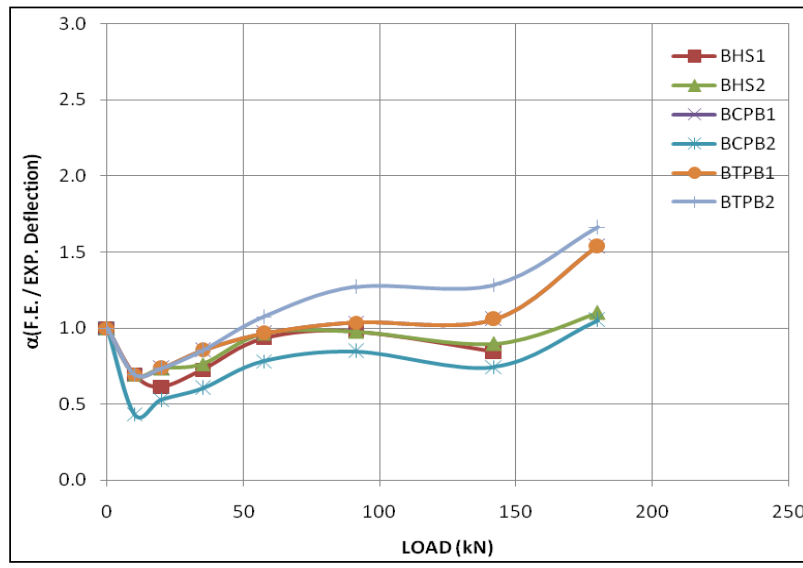

Figure(12) F.E./Experimental Deflection $\operatorname{Ratio}(\alpha)$

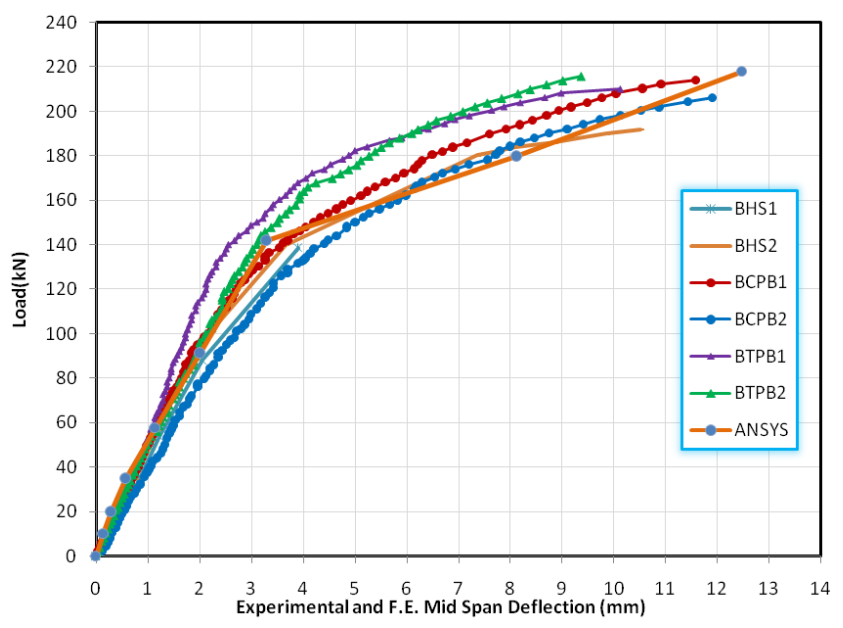

Figure (14) Comparison between F.E. and Experimental Deflection at Midspan

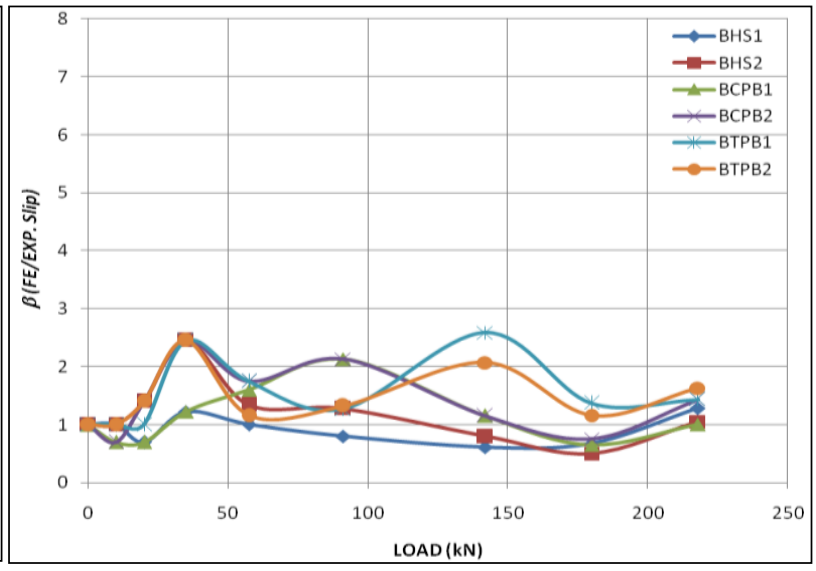

Figure(13)F.E./Experimental Slip Ratio $(\beta)$

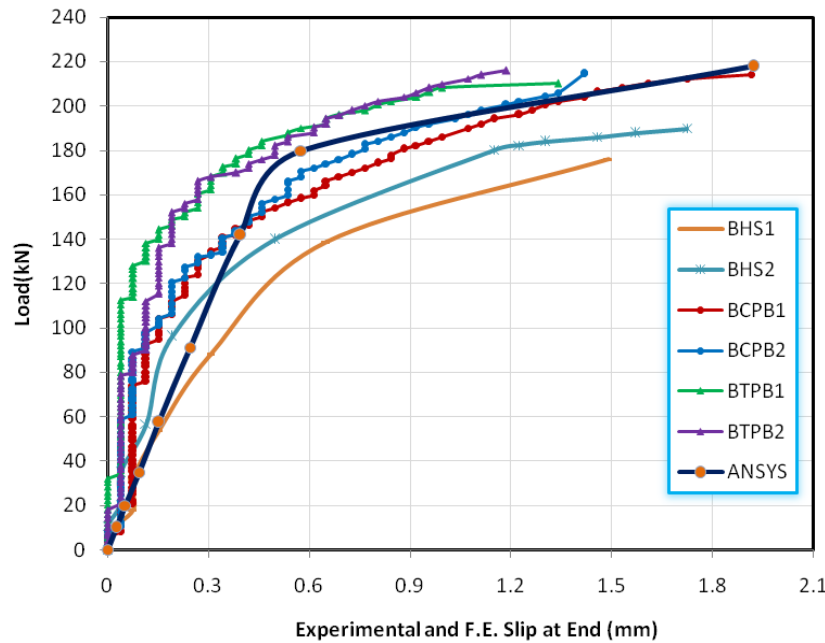

Figure (15) Comparison between F.E. and Experimental Slip at Ends

The finite element results in terms of cracks and Von Mises stresses in concrete are also shown in Figs.(16 and 17).

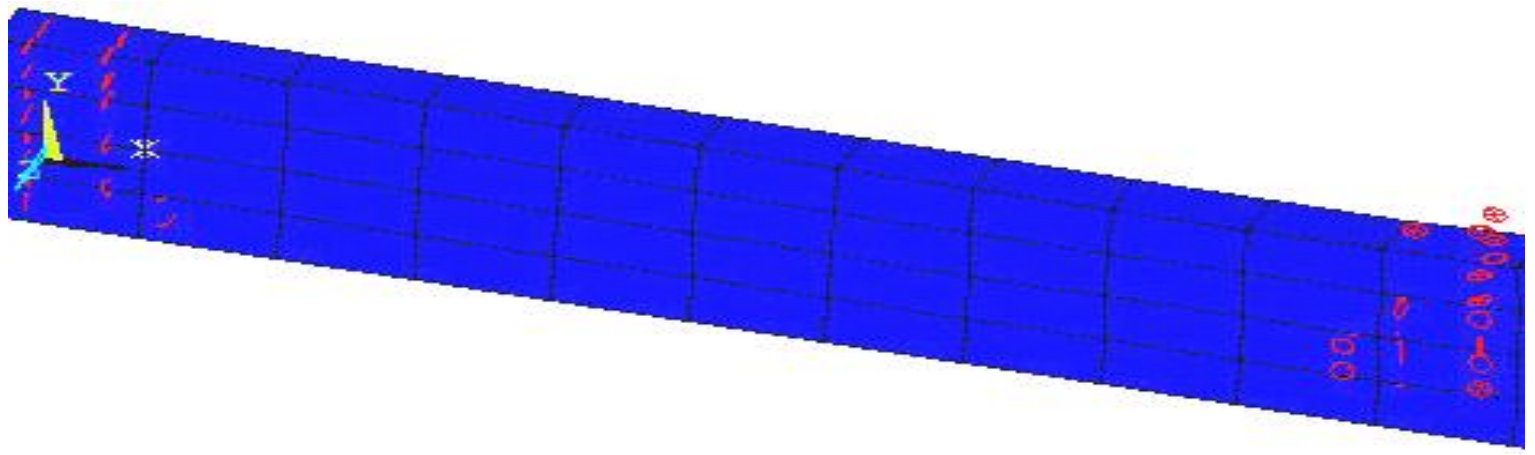

Figure (16) Finite Element Cracks Patterns in Concrete Slab 


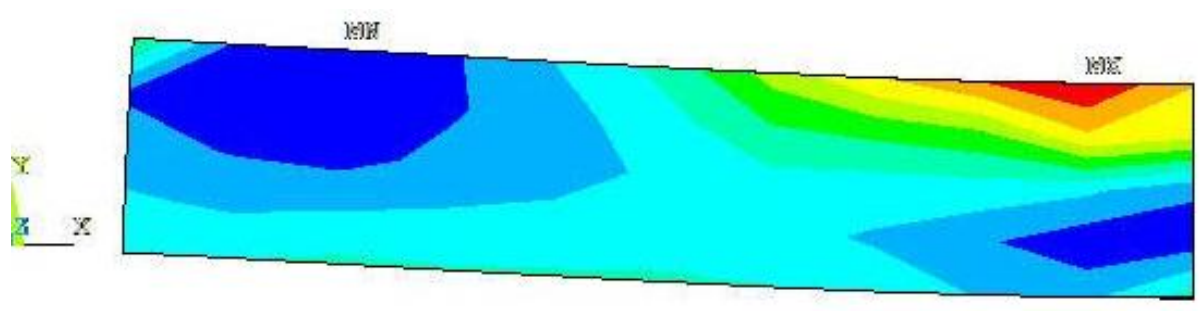

\section{$\begin{array}{lllllllll}2.75 & 5.88 & 9.07 & 13.13 & 15.26 & 18.38 & 21.51 & 24.63 & 27.76 \\ 30.87\end{array}$ \\ Figure (17) Finite Element Von Mises Stress in Concrete Slab (MPa)}

\section{Discussion}

The experimental results show that the common shape of failure is the shear failure, for the three test groups. The results of the three groups listed in Table (6) show that the uses of perfobond connector in composite beam enhance the behavior of the beam represented by reducing deflection and slip and increasing the resistance. Whereas, the yield loads resistance is increased comparing with the stud connector's group of about $12 \%$ and $19 \%$ for circular and triangular perfobond connectors' groups respectively. Also, the ultimate load resistance is increased comparing with the stud connector's group of about $14 \%$ and $16 \%$ for circular and triangular perfobond connectors' groups respectively. As well as the newly suggested triangular perfobond connector give an average ultimate strength $212.9 \mathrm{kN}$ which is higher than the average ultimate strength circular perfobond connector given as $210.04 \mathrm{kN}$ with a difference percentage of about $1.36 \%$.

The results shown in Figs.(8 and 9) show that the loads required to obtain the slips of beams with perfobond connectors are more than that required for stud connector, as well as the loads of beams with triangular perfobond are more than that required for circular one. These results approved the applicability and validity of using the newly suggested type of perfobond connector.

The finite element model is validated through comparing their results with those obtained experimentally. The differences between the finite element and experimental results, listed in Table (7), are shown to be $5 \%$ and $11 \%$ in for beams constructed with perfobond connectors, and $20 \%$ for beams with stud connectors at yielding stage. At ultimate stage, the differences are about $2 \%, 4 \%$ and $16 \%$ for beams constructed with triangular and circular perfobond connectors and stud connectors respectively. The results listed in Table (8) show that the deflections and the slips predicted from finite element model are acceptable comparing with those measured experimentally at yielding stage, with a slightly large differences obtained at the ultimate stage considering the differences in ultimate loads produced from finite element model and the experimental results. Fig.(12) shows that the deflection obtained from the finite element model during different load stages are compatible with those measured experimentally. Fig.(13) shows that the slip obtained from the finite element model are varied with those measured experimentally at the early stages and mostly converged after yielding, which also shown in Figs (14 and 15) in terms of load - deflection curves and load-slip curves respect.

It can be shown from Fig.(16), which represents the crack patterns, that the cracks resulted under the applied loads, which it compatible with the experimental results obtained and shown in Fig.(7). The results shown in terms of Von Mises in Fig.(17) at the stage of failure explain clearly the locations of stress concentrations, whereas the concentration of stresses under the loads area decreased with the increasing of distance from the load points. 


\section{Conclusion}

This paper described an experimental study that focused on the behavior and strength of steel-concrete composite beams with different types of shear connectors. The main conclusions drawn from this study are the following.

- Steel-concrete composite beams designed and constructed with perfobond shear connectors can develop higher ultimate strength of about $14 \%$ and $16 \%$ for circular and triangular perfobond connectors' groups respectively compared with the beams constructed with stud shear connectors.

- The tests confirmed that the newly suggested triangular perfobond connector is applicable and give an average ultimate strength higher than the circular perfobond connector of about $1.36 \%$.

- The finite element model used for analysis of steel-concrete composite beam validated through comparing the results with those measured experimentally.

- The results indicate that the finite element model can predict ultimate resistance of beam with $0.9 \%$ to $5.7 \%$ differences comparing with beams constructed with perfobond connectors and $11.9 \%$ to $19.2 \%$ differences comparing with beams constructed with stud connectors. This might be lead to conclude that more detailed investigation on the simulation of composite beam using finite element method is required in the future.

- The finite element study described in this paper concentrated on using one model to simulate the nonlinear behavior of concrete. Further investigation are needed to cover the models used to simulate the nonlinear behavior of concrete.

\section{Acknowledgement}

This work is a part of an M.Sc. research project, in Civil Engineering Department, College of Engineering, Mosul University. The authors would like to thank the Civil Engineering laboratory staff in College of Engineering, University of Mosul for their cooperation.

\section{References}

[1] Knowles, P.R. 1973. "Composite Steel and Concrete Construction". Butterworth Co. Ltd., London, , ISBN: 040870439X, 200pp.

[2] Al-Juboory, I.M.A., 2011, "Study of the Mechanical Shear Connectors Behaviour in Composite Beams (Steel-Concrete)", M.Sc.Thesis, Civil Engineering Department, University of Mosul, Iraq.

[3] Lawson, R.M., and Chun, K.F., 1994. "Composite Beam Design to Eurocode 4", SCI Publication, Berkshire, U.K., ISBN: 1870004868, 135pp.

$\mathrm{http}$ ///ebookee.org/Composite-Beam-Design-to-Eurocode-4_171860.html

[4] Nie, J., and Cai, C. S., 2003, "Steel-Concrete Composite Beams Considering Shear Slip Effects ", Journal of Structural Engineering, Vol. 129, No. 4, April , pp. 495-506. DOI: 10.1061/ ASCE!0733-9445 2003!129:4 495!

[5] Nie, J., Xiao, Y., and Chen, L., 2004, "Experimental Studies on Shear Strength of Steel -Concrete Composite Beams", Journal of Structural Engineering, Vol. 130, No. 8, pp.1206-1213. DOI: 10.1061/(ASCE)0733-9445(2004)130:8(1206)

[6] Liang, Q.Q., Uy, B., Bradford.A., and Ronagh, H.R., 2005, "Strength Analysis of Steel-Concrete Composite Beams in Combined Bending and Shear", Journal of Structural Engineering, Vol.131, No.10, pp.1593-1600. DOI:10.1061/_ASCE_0733-9445_2005_131:10_(1593)

[7] Queiroz, F.D., Vellasco, P.C.G.S., and Nethercot, D.A., 2007, "Finite Element Modeling of Composite Beams with Full and Partial Shear Connection", Journal of 
Constructional Steel Research, Vol. 63, 2007, pp.505-521. DOI:10.1016/j.jcsr.2006.06.003

[8] Queiroz, F.D., Queiroz,G., and Nethercot, D.A.,2009, "Two-Dimensional FE Model for Evaluation of Composite Beams, I: Formulation and Validation", Journal of Constructional Steel Research, Vol. 65, 2009, pp.1055-1062.

doi:10.1016/j.jcsr.2009.01.006

[9] Iraqi Specifications IQS No. 5, 1984, "Properties of Normal Portland Cement", Iraqi Central Organization of Standardization and Quality Control , Ministry of Planning, Iraq.

[10] BS.882-1992," Aggregates from Natural Source for Concrete", British Standard Institution, 1992.

[11] Moaveni, S., 1999, "Finite Element Analysis Theory and Application with ANSYS", Prentice Hall Inc., New Jersey, ISBN 0-13-785098-0, pp-272

[12] Gattesco N., "Analytical modeling of nonlinear behaviour of composite beams with deformable connection". Journal of Constructional Steel Research 1999; 52:195-218. DOI: 10.1016/S0143-974X(99)00026-7

[13] Owen, D.R.J., and Hinton, E., 1980, "Finite Element in Plasticity, Theory and Practice", Pineridge Press Limited, Swansea, U.K. ISBN: 0-906674-05-2, pp-603.

[14] Kohnke, P., 2001, “ANSYS, Inc. Theory Manual”, $12^{\text {th }}$ ed, SAS IP, Inc, USA, pp1266.

\section{List of Symbols}

$\begin{array}{cl}f_{c} & \text { Concrete cylinder compressive strength } \\ f c u & \text { Concrete cube compressive strength } \\ f y & \text { Steel yield strength } \\ f u l t . & \text { Steel ultimate strength } \\ b f & \text { Flange width } \\ d & \text { Depth } \\ t f & \text { Thickness of flange } \\ t w & \text { Thickness of web } \\ P_{\text {yield }} & \text { Yield load } \\ \delta_{u l t .} & \text { Deflection } \\ P_{\text {ult. }} & \text { Ultimate force } \\ f t & \text { Tensile cracking stress } \\ \alpha & \text { finite element to experimental deflection ratio } \\ \beta & \text { finite element to experimental slip ratio }\end{array}$

The work was carried out at the college of Engineering. University of 